\title{
North Atlantic Oscillation drives the annual occurrence of an isolated, peripheral population of the brown seaweed Fucus guiryi in the Western Mediterranean Sea
}

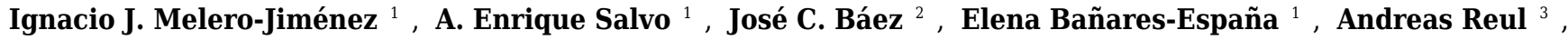 \\ Antonio Flores-Moya Corresp. 1 \\ ${ }^{1}$ Departamento de Biología Vegetal (Botánica), Facultad de Ciencias, Universidad de Málaga, Málaga, Spain \\ 2 Centro Oceanográfico de Canarias, Instituto Español de Oceanografía, Santa Cruz de Tenerife, Spain \\ 3 Departamento de Ecología y Geología, Facultad de Ciencias, Universidad de Málaga, Málaga, Spain \\ Corresponding Author: Antonio Flores-Moya \\ Email address: floresa@uma.es
}

The canopy-forming, intertidal brown (Phaeophyceae) seaweed Fucus guiryi is distributed along the cold-temperate and warm-temperate coasts of Europe and North Africa. Curiously, an isolated population develops at Punta Calaburras (Alboran Sea, Western Mediterranean) but thalli are not present in midsummer every year, unlike the closest (ca. $80 \mathrm{~km}$ ), perennial populations at the Strait of Gibraltar. The persistence of the alga at Punta Calaburras could be due to the growth of resilient, microscopic stages as well as the arrival of few-celled stages originating from neighbouring localities, and transported by the permanent Atlantic Jet flowing from the Atlantic Ocean into the Mediterranean. A twentysix year time series (from 1990 to 2015) of midsummer occurrence of $F$. guiryi thalli at Punta Calaburras has been analysed by correlating with oceanographic (sea surface temperature, an estimator of the Atlantic Jet power) and climatic factors (air temperature, rainfall, and North Atlantic Oscillation -NAO-, and Arctic Oscillation -AO- indexes). The midsummer occurrence of thalli clustered from 1990-1994 and 1999-2004, with sporadic occurrences in 2006 and 2011. Binary logistic regression showed that the occurrence of thalli at Punta Calaburras in midsummer is favoured under positive NAO index from April to June. It has been hypothesized that isolated population of $F$. guiryi should show greater stress than their congeners of permanent populations, and to this end, two approaches were used to evaluate stress: one based on the integrated response during ontogeny (developmental instability, based on measurements of the fractal branching pattern of algal thalli) and another based on the photosynthetic response. Although significant differences were detected in photosynthetic quantum yield and water loss under emersion conditions, with thalli from Punta Calaburras being more affected by emersion than those from Tarifa, the developmental instability showed that the population from Tarifa suffers higher stress during ontogeny than that from Punta Calaburras. In conclusion, this study 
demonstrates the teleconnection between atmospheric oscillations and survival and proliferation of marine macroalgae. 
1 North Atlantic Oscillation drives the annual occurrence of an isolated,

\section{2 peripheral population of the brown seaweed Fucus guiryi in the Western}

\section{Mediterranean Sea}

4

5 Ignacio J. Melero-Jiménez ${ }^{\mathrm{a}}$, A. Enrique Salvo ${ }^{\mathrm{a}}$, José C. Báez ${ }^{\mathrm{b}}$, Elena Bañares-España ${ }^{\mathrm{a}}$, Andreas

6 Reulc $^{c}$, Antonio Flores-Moya ${ }^{\mathrm{a}^{*}}$

7

8 a Departamento de Biología Vegetal (Botánica), Facultad de Ciencias, Universidad de Málaga,

9 Málaga, Spain

10 b Instituto Español de Oceanografía, Centro Oceanográfico de Canarias, Santa Cruz de

11 Tenerife, Spain

$12{ }^{\mathrm{c}}$ Departamento de Ecología y Geología, Facultad de Ciencias, Universidad de Málaga, Málaga,

13 Spain

14

$15 *$ Corresponding author

16 E-mail address: floresa@uma.es 


\section{ABSTRACT}

8

The canopy-forming, intertidal brown (Phaeophyceae) seaweed Fucus guiryi is distributed along the cold-temperate and warm-temperate coasts of Europe and North Africa. Curiously, an isolated population develops at Punta Calaburras (Alboran Sea, Western Mediterranean) but thalli are not present in midsummer every year, unlike the closest (ca. $80 \mathrm{~km})$, perennial populations at the Strait of Gibraltar. The persistence of the alga at Punta Calaburras could be due to the growth of resilient, microscopic stages as well as the arrival of few-celled stages originating from neighbouring localities, and transported by the permanent Atlantic Jet flowing from the Atlantic Ocean into the Mediterranean. A twenty-six year time series (from 1990 to 2015) of midsummer occurrence of $F$. guiryi thalli at Punta Calaburras has been analysed by correlating with oceanographic (sea surface temperature, an estimator of the Atlantic Jet power) and climatic factors (air temperature, rainfall, and North Atlantic Oscillation -NAO-, and Arctic Oscillation -AO- indexes). The midsummer occurrence of thalli clustered from 1990-1994 and 1999-2004, with sporadic occurrences in 2006 and 2011. Binary logistic regression showed that the occurrence of thalli at Punta Calaburras in midsummer is favoured under positive NAO index from April to June. It has been hypothesized that isolated population of F. guiryi should show greater stress than their congeners of permanent populations, and to this end, two approaches were used to evaluate stress: one based on the integrated response during ontogeny (developmental instability, based on measurements of the fractal branching pattern of algal thalli) and another based on the photosynthetic response. Although significant differences were detected in photosynthetic quantum yield and water loss under emersion conditions, with thalli from Punta Calaburras being more affected by emersion than those from Tarifa, the 
40 developmental instability showed that the population from Tarifa suffers higher stress during

41 ontogeny than that from Punta Calaburras. In conclusion, this study demonstrates the

42 teleconnection between atmospheric oscillations and survival and proliferation of marine

43 macroalgae. 
44

45

46

47

\section{INTRODUCTION}

The canopy-forming, brown (Phaeophyceae) seaweed Fucus guiryi G. I. Zardi et al. inhabits the littoral zone of cold-temperate and warm-temperate European and African coasts of the northern Atlantic Ocean (Zardi et al., 2011). This species is more abundant in upwelling areas, which are considered to be climatic change refugia (Lourenço et al., 2016). The known southern limit of distribution occurs in Dakhla, Western Sahara (Lourenço et al., 2016), but the range does not extend continuously into the Mediterranean Sea (Zardi et al., 2011). However, an isolated population develops at Punta Calaburras (Alboran Sea, Western Mediterranean; Fig. 1A-B), around $80 \mathrm{~km}$ from the nearest populations in the Strait of Gibraltar (Conde, 1989). It has been hypothesized that the presence of $F$. guiryi (previously known as F. spiralis and F. spiralis var. platycarpus; see Zardi et al., 2011) at Punta Calaburras is favoured by the "Atlantic Jet" current flowing from the Atlantic Ocean into the Mediterranean Sea through the Strait of Gibraltar (Bellón, 1953; Conde \& Seoane-Camba, 1981). Punta Calaburras is located at the edge of the North Western Alboran upwelling (Reul et al., 2006; Muñoz et al., 2015; Macías et al., 2016), which is in agreement with the hypothesis that upwelling areas provide thermal refugia for $F$. guiryi (Lourenço et al., 2016). At Punta Calaburras, the Atlantic Jet (AJ) approaches the Spanish coast before deflecting towards the Moroccan coast (Fig. 1A). This current compensates for the negative water balance in the Mediterranean Sea due to the loss of water by evaporation, which is greater than the inputs by precipitation and rivers (Rodríguez, 1982; Parrilla \& Kinder, 1987. Although F. guiryi (as F. spiralis; see Zardi et al., 2011) was found in 1987 on the Mediterranean coast of France at Gruissan (Aude), it was probably introduced via oyster culture in the lagoons along the Mediterranean French coasts (Sancholle, 1987); this introduced population is not comparable to the natural population of Punta Calaburras. 
The singularity of the isolated population of F. guiryi at Punta Calaburras inspired us to start a survey in 1990 (linked to the field teaching at the university of the corresponding author AFM), which revealed that the population was always detected in winter. However, in some years the thalli did not survive midsummer, in contrast to the nearby perennial populations in the Strait of Gibraltar and throughout the range of this species. The occurrence of this population of $F$. guiryi must be determined by environmental conditions, so a first aim of this study was to analyse the role of the oceanographic and atmospheric factors controlling the presence of thalli at Punta Calaburras in midsummer. For this purpose, the time series (from 1990 to 2015) of presence/absence of $F$. guiryi thalli at Punta Calaburras was analysed by binary logistic regression, using two kinds of independent, explanatory variables. First, a proxy for the powerful incoming current from the Atlantic Ocean into the Alboran Sea, which becomes evident by changes in sea surface temperature (SST; lower SST with higher current flow; Vargas-Yáñez et al., 2002; Renault et al., 2012). Second, the North Atlantic Oscillation (NAO) and the Arctic oscillation (AO) can account for the most important climate variability in the Northern Hemisphere. In fact, it has been found that both atmospheric oscillations affect the SST in the Alboran Sea (Báez et al., 2013), but the link between occurrence or productivity of microalgae or seaweeds and atmospheric oscillations remains almost unexplored (Moore et al., 2008; Folland et al., 2009; Gamboa et al., 2010; Smale et al., 2013; Báez et al., 2014).

The population of $F$. guiryi occurring at the limit of the species' distribution, geographically isolated and composed of a low number of individuals, could experience higher stress than the populations inhabiting the Strait of Gibraltar. This conjecture is based on the notion that peripheral populations of organisms are typical cases of "living at the edge" (Channell \& Lomolino, 2000; Helmuth et al., 2006; Eckert et al., 2008; Peterman et al., 2013), 
91 with organisms showing signs of physiological stress (Shumaker \& Babble, 1980). In fact,

92 several studies have revealed physiological stress and changes in growth and reproductive

93 success in F. guiryi inhabiting the edge of its geographical distribution, compared to core

94 populations (Ferreira et al., 2014; Zardi et al., 2015). Following this idea, a second aim of this

95 study was to carry out a comparative study of individuals at Tarifa (Strait of Gibraltar) (Fig. 1A-

96 C) vs. Punta Calaburras, during the summer of 2011, a year when thalli occurred at both places.

97 For this purpose, we evaluated stress via a physiological approach based on photosynthesis as

98 well as the whole-organism response by assessing developmental stability. Quantum yield from

99 photosystem II photochemistry responds to the alteration of optimum conditions, which could

100 indicate that photosynthesis is being affected (Baker \& Oxborough, 2004). On the other hand,

101 individuals integrate stress conditions throughout their ontogeny, termed developmental

102 instability (Clarke \& McKenzie, 1987; McKenzie \& Clarke, 1988; Emlen et al., 1993; Palmer,

103 1994). Developmental instability is more sensitive than traditional measures of stress (Graham et

104 al., 1993; Clarke, 1995). It is responsive to a wide range of stressors (Zakharov 1992; Graham et

105 al., 1993) and it is ideally suited for detecting stress in the field (Graham et al., 1993). Therefore,

106 it could be expected that a higher rate of development instability arises at the limits of

107 distribution of organisms, compared to instability in core populations, because in peripheral areas

108 combinations of environmental factors occur that adversely affect growth, reproduction, and

109 ultimately survival of organisms (Zakharov, 1992; Clarke, 1995).

112 MATERIALS AND METHODS

113 Sampling locations and surveys 
114 Study sites were Punta Calaburras $\left(36^{\circ} 30^{\prime} 28^{\prime \prime} \mathrm{N}, 004^{\circ} 38^{\prime} 08^{\prime \prime} \mathrm{W}\right)$ and Tarifa $\left(36^{\circ} 00^{\prime} 03^{\prime \prime} \mathrm{N}\right.$,

$115005^{\circ} 36^{\prime} 37^{\prime \prime} \mathrm{W}$ ) (Fig. 1A). Both locations have a similar hot-summer Mediterranean climate

116 (group Csa, Köppen-Geiger climate classification system). Overall mean precipitation ranges

117 from 0 or $1 \mathrm{~mm}$ in July, to $93 \mathrm{~mm}$ or $146 \mathrm{~mm}$ in November, at Punta Calaburras or Tarifa,

118 respectively. Air temperature is also similar at both study sites (overall minimum mean in

119 January of $12.5^{\circ} \mathrm{C}$ in Punta Calaburras, and of $11.8^{\circ} \mathrm{C}$ in Tarifa; overall maximum mean in

120 August of $25.2{ }^{\circ} \mathrm{C}$ in Punta Calaburras vs. $23.4{ }^{\circ} \mathrm{C}$ in Tarifa). Surface water temperature ranges

121 from $15-16^{\circ} \mathrm{C}$ in March to $22-24{ }^{\circ} \mathrm{C}$ in August in both locations. Moreover, although

122 environmental conditions at both sampling points differ at short-term, a biogeographical

123 subregion (from the Strait of Gibraltar to Punta Calaburras) has been recognized based on the

124 oceanographic conditions in the northern Mediterranean-Atlantic transition zone. This subregion

125 shows a close agreement with the species composition of the littoral and sublittoral benthic

126 communities (Bermejo et al., 2015). Consequently, we assumed that comparison of both

127 populations of $F$. guiryi is worthwhile.

The sampling location at Punta Calaburras consists of rocks (schists and gneiss)

129 protruding from the mean sea level up to $30 \mathrm{~cm}$ at low spring tide, occupying a surface area of

ca. $150 \mathrm{~m}^{2}$. The thalli, when they are present, proliferate over almost all the rocks. Consequently,

all emergent rocks were visually surveyed during low spring tides, during ca. $1 \mathrm{~h}$ searches across

all microhabitats. The survey allowed us to detect macrothalli but not possible resilient,

microscopic stages. The presence of thalli of F. guiryi was checked annually in February-March,

and in July-August (Table 1), from 1990 to 2015. Tarifa presents a subhorizontal sandstone 
137 growing up to $30 \mathrm{~cm}$ above low spring tide level were collected and analyzed for developmental 138 instability and photosynthetic performance (see below).

139 We observed thalli of F. guiryi at Punta Calaburras every year of the survey in February-

140 March, but thalli did not always persist into midsummer. The time series of the occurrence of

141 thalli in midsummer was initially analysed taking into account two aspects: the distribution of the

142 presence of thalli and the tendency of the occurrence. The annual occurrence distribution was

143 checked with the test due to Prahl (1999) for a stationary Poisson process (randomly distributed

144 throughout the time). The tendency of the annual occurrence distribution was analysed by the

145 Laplace test (Cox \& Lewis, 1978).

Analysis of the annual occurrence as a function of oceanographic and atmospheric variables

150

151 The relationship between the presence/absence in midsummer of $F$. guiryi thalli at Punta

152 Calaburras from 1990 to 2015, and the temperature, rainfall, NAO, AO and SST, was addressed by binary logistic regressions, widely used for establishing relationships between environmental independent variables and the probability response of target variables (Zuur et al., 2007). Temperature and rainfall mean monthly data were obtained from the Agencia Española de Meteorología (Fuengirola station, $4 \mathrm{~km}$ to the east of Punta Calaburras). Of the atmospheric

157 oscillations, NAO is the most important mechanism responsible for the interannual climate 158 variability in SW Europe, particularly during the winter (Hurrell, 1995; Hurrell et al., 2003).

159 The AO also affects the overall mean of weather conditions in SW Europe. According to 
160 Thompson \& Wallace (1998) the AO explains anomalies in the Arctic region according to the 161 polar vortex. Thus, when the AO index is positive (characterized by a strengthening of the polar

162 vortex), surface pressure is low in the polar region, and the opposite occurs when the index is 163 negative. Monthly AO and NAO index values were obtained from the free-access web sites of 164 the U.S. National Oceanic and Atmospheric Administration, 165 http://www.cpc.ncep.noaa.gov/products/precip/CWlink/daily_ao_index/ao.shtml, and 166 http://www.cpc.ncep.noaa.gov/products/precip/CWlink/pna/nao.shtml, respectively. Finally, the 167 power of the Atlantic current entering the Mediterranean Sea was estimated by the SST values 168 close to Punta Calaburras (the higher the flow of AJ water, the lower SST is; Parrilla \& Kinder, 1987). Data of SST were obtained from the free-access web site from the Centro Oceanográfico 170 de Málaga (sede Fuengirola), Instituto Español de Oceanografía, http://www.ma.ieo.es/gcc/playafuengirola_taireyagua_anomalias.xls. For the analysis, we tested the monthly values of environmental variables from the same month as well as the overall mean figures from two to six previous months. We assessed the significance of the variables in the model using the Wald test (Wald, 1943), the calibration of the model using the Hosmer \& Lemeshow test (Hosmer \& Lemeshow, 1980), its discrimination capacity using the area under the curve (AUC) of the receiving operator characteristics (Lobo et al., 2008), and its explanatory power using the Nagelkerke $R^{2}$ (Nagelkerke, 1991). that favoured the presence of $F$. guiryi thalli, the opening gap between the values considered as clearly probable $(p>0.6)$ or clearly improbable $(p<0.4)$. It must be taken into account that $p=0.5$ means that the presence or the absence of the thalli have a similar probability. We then compared

182 the correct classification rate of the models for years clearly probable and clearly improbable for 
183 a presence of thalli, and simultaneously we identified the levels of the environmental variables 184 associated with the relevant probability levels.

\section{Developmental instability}

All the species in the genus Fucus exhibit self-symmetry, i.e. symmetry across scale (Corbit \&

Garbary, 1995). We estimated the developmental instability in F. guiryi individuals by

191

deviations of the self-symmetry of thalli, by using the box-counting procedure (Mandelbrot, 1983; Iannaccone \& Khokha, 1996). At Punta Calaburras, a single thallus was collected from the center of a randomly placed $15 \times 15 \mathrm{~cm}$ quadrat, from each of the 20 different protruding rocks (those reaching the maximum height over the sea surface). At Tarifa, a $5 \mathrm{~m}$ length horizontal transect was located parallel to the sea surface and a thallus was collected every $20 \mathrm{~cm}$ from the center of a quadrat of $15 \times 15 \mathrm{~cm}$. At both study sites, the sampling stopped when the twenty-first thallus lacking grazing marks was collected. This precaution was taken because grazing marks alter the thallus shape and, consequently, the self-symmetry; thus, individuals showing no damage were selected (around $15 \%$ of thalli showed herbivore marks, especially by the fish Sarpa salpa). Curiously, grazing marks were exclusively found on thalli collected in Tarifa, possibly due to the fact that the thalli inhabiting Punta Calaburras are located in the upper part of the tidal range of the area. Thalli were placed between two transparent acetate foils, avoiding overlapping the fronds, and they were scanned in TIFF format (300 ppi). The scanned images were superimposed on grids with exponentially increasing box sizes $(0.125,0.25,0.5,1,2$ and 4 $\mathrm{cm}^{2}$ ). The number of boxes in which at least part of the thallus occurred were counted using an 
206 image analysis system Visilog 6.3 (Noesis, France). Twenty independent thalli were processed

207 from each location. Because the overall positioning of the boxes can affect the results of a box

208 count (Walsh \& Watterson, 1993; Schulze et al., 2008), the counting of the boxes was carried out

209 three times (named "replicates"), repositioning the thalli over the acetate foils with the grids

210 every time. We then regressed the natural log of the number of occupied boxes against the

211 natural log of the size of each box. The absolute value of the slope of the regression line is the

212 fractal dimension (a measure of the space filled by the individual). Developmental instability is

213 the degree to which the individual failed to fit the idealized phenotype, and is measured as the

214 standard error of the estimate $\left(S_{Y \cdot X}\right.$, computed as the square root of the residual mean square of

215 the ANOVA regression of the linear fit). The value of $S_{Y \cdot X}$ is an overall indication of the accuracy

216 with which the fitted regression function predicts the dependence of $Y$ on $X$. Under non-stressful

217 conditions, all points should lie on the regression line.

218 A two-level nested ANOVA (model: $y=$ overall mean + locations + replicates [locations $]+$ 219 error) was performed to compare the $S_{Y \cdot X}$ values. The factor "locations" correspond to the Tarifa 220 and Punta Calaburras populations, whereas the factor "replicates [locations]" corresponds to the

221 three independent measurements of $S_{Y \cdot X}$ of each thallus from both locations. The homogeneity of 222 variances was previously checked with Bartlett's test.

Measurement of natural solar radiation and temperature in air and water

226

227 The measurements were carried out on $16^{\text {th }}$ July 2011 at Tarifa, and on the following day at 228 Punta Calaburras. Daily changes in PAR $(\lambda=400-700 \mathrm{~nm})$ were measured using a LI-190R PAR 
229

230

231

232

233

234

235

236

237

238

239

240

241

242

243

244

245

246

247

248

249

250

251

sensor connected to a LI-1400 data logger (LI-COR, Lincoln, NE, USA). The ultraviolet A $(\lambda=$ $315-400 \mathrm{~nm})$ and ultraviolet $\mathrm{B}(\lambda=280-315 \mathrm{~nm})$ bands were measured using a RM12 device

(Dr. Gröbel, Ettlingen, Germany) connected to the respective UVA and UVA sensors.

Measurements were made every $30 \mathrm{~min}$, and data were fit to a single sinusoid with the free software PAST ver. 2.17 (Hammer et al., 2001); the daily doses of each channel were calculated by integrating the area under the sinusoidal curves. Air temperature $\left( \pm 0.1^{\circ} \mathrm{C}\right)$ in the shade was measured with a sensor connected to a LI-1400 data logger. Seawater temperature $\left( \pm 0.1^{\circ} \mathrm{C}\right)$ was measured with the temperature sensor of a Crison2 OXI-92 (Crison, Spain) oxymeter.

\section{In vivo measurements of chlorophyll $a$ fluorescence}

A day-long record (from 06.00 to 18.00 , Coordinated Universal Time-UTC-) of the photosynthetic performance of $F$. guiryi was carried out on the same days as the solar radiation measurements. The sampling day was selected to correspond to a spring tide, with a maximum tidal height ca. $1.2 \mathrm{~m}$ at Tarifa and ca. $0.4 \mathrm{~m}$ at Punta Calaburras (Fig. 2). Because the weather was sunny without clouds and with similar air and seawater temperatures (see Results), we assumed that the photosynthetic performance measured on the two consecutive days at the different locations should be comparable. Five independent thalli were randomly collected before sunset from the higher eulittoral of Tarifa and Punta Calaburras. For this purpose, we initially randomly collected 20 thalli at each location, as explained in the Developmental instability section above. Then, the thalli were randomly numbered from 1 to 20 , and we selected five thalli whose numbers correspond to those that had been generated with a random integer generator 
252 accessible at free-access web site https://www.random.org/integers/. The thalli were placed in a

$25325 \mathrm{~L}$ white polyvinylchloride tank in natural seawater from the collection site. The tank was

254 placed close to the attachment site of the alga, in an unshaded place. To avoid nutrient depletion

255 and changes in temperature in the tank, seawater was renewed completely every $10 \mathrm{~min}$. The

256 measurements were carried out every $2 \mathrm{~h}$ from sunrise to sunset; from 10.00 to $14.00 \mathrm{UTC}$; an

257 extra set of measurements was carried out on thalli exposed to air from 09.30 UTC.

258 Fresh mass (FM) on thalli in situ was measured with an ELB120 portable analytical

259 balance $( \pm 0.01 \mathrm{~g})$ (Shimadzu, Kyoto, Japan) after thalli were blotted dry with paper towel. The

260 same samples were transported to the laboratory and dried at $60^{\circ} \mathrm{C}$ for $48 \mathrm{~h}$ to determine their

261 dry mass (DM). The percentage of water content of thalli was determined as:

262

263

$$
\% \text { Water content }=\left(\frac{\mathrm{FM}-\mathrm{DM}}{\mathrm{FM}}\right) \times 100
$$

PAM-2000 fluorimeter (Walz, Effeltrich, Germany) following Schreiber et al. (1986). The $30 \mathrm{~min}$.

The relative electron transport rate $\left(E T R_{\text {rel }}\right)$ was estimated as:

$$
E T R_{\text {rel }}=\Phi_{\text {PSII }} \times I
$$

273 where $I$ is the incident irradiance of $\operatorname{PAR}(\lambda=400-700 \mathrm{~nm})$ and $\Phi_{\mathrm{PSII}}$ is the quantum yield of PSII photochemistry. 
276 and $F_{\mathrm{v}} / F_{\mathrm{m}}, \Phi_{\mathrm{PSII}}$ and $E T R_{\text {rel }}$ (in air and water), was analysed by a two-way, model I ANOVA.

277 Differences, when obtained, were checked by the Student-Newman Keuls (SNK) procedure.The

278 homogeneity of variances was previously checked with the Bartlett's test. The Pearson's

279 correlation coefficient was computed for the relationships between hydration of thalli and

280 photosynthetic performance parameters.

281

282

283

\section{Statistical software analysis}

284

285

286

The exp and tendency tests in the time series were performed using the free software

PAST ver. 2.17 (Hammer et al., 2001) accessible at

287

288

289

290

291

292

293

294

295

296

297

http://nhm2.uio.no/norlex/past/download.html. The remaining statistical analyses were carried out using R (2013).

\section{RESULTS}

\section{Analysis of the time series of occurrence}

The occurrences in midsummer of thalli of F. guiryi at Punta Calaburras through the years 1990 to 2015 were clustered $(M=0.96 ; M$-expected $=0.36, p<0.0001)$ from 1990-1994 and 19992004, with sporadic occurrences in 2006 and 2011 (Table 1). A trend in the occurrence of thalli 
298 in midsummer throughout of the time series was not detected $\left(U\right.$-Laplace test $=-3.8 \times 10^{-15}, p=$ 299 1).

We found a significant positive relationship between the NAO for the months from April

301

302

303

304

305

306

307

308

309

310

311

312

313

314

315

316

317

318

319

320

to June $\left(\mathrm{NAO}_{3}\right)$ of each year and the probability of the presence of $F$. guiryi $\left(\chi^{2}=13.530, d f=1\right.$, $p=0.0002$; Wald's test $=5.994, d f=1, p=0.014$; Table 2 ) according to the logit $y$ function:

$$
y=3.418 \times \mathrm{NAO}_{3}+0.239
$$

The $95 \%$ confidence limits for the intercept and for the explanatory variable $\mathrm{NAO}_{3}$ were $[-0.779$, $1.263]$ and $[0.682,6.138]$, respectively; that is to say, a logit $y$ function in which the intercept is deleted could also be used because its contribution to the model was not significant (the confidence interval includes the figure 0 ). This model was well calibrated (Hosmer and Lemeshow's test $=4.145, d f=7, p=0.7661)$, meaning that the differences between observed and predicted frequencies were not significant. The overall ability of discrimination and the general explanatory power of the model were high $\left(\mathrm{AUC}=0.876\right.$ and Nagelkerke $R^{2}=0.541$, respectively).

According to the logit $y$ function, the probability $p$ of the occurrence of $F$. guiryi thalli in midsummer computed as $\exp ^{y /}\left(1+\exp ^{y}\right)$, was calculated (Fig. 3). Based on relevant $p$ values, we estimated the correct classification of years in which the $\mathrm{NAO}_{3}$ index favoured the presence or the absence of $F$. guiryi thalli. The model clearly identified three of four highly probable years ( $p>0.6$, corresponding to $\mathrm{NAO}_{3}>0.048$ ) for the presence of $F$. guiryi thalli, and simultaneously, all of the clearly improbable years $\left(p>0.4\right.$, corresponding to $\left.\mathrm{NAO}_{3}<-0.189\right)$ were correctly assigned. 


\section{Developmental instability}

The standard error of the regression $\left(S_{Y \cdot X}\right)$ derived from the box-counting method was used as a proxy for developmental instability in $F$. guiryi. The comparison of the $S_{Y \cdot X}$ values showed that

327 the replicates [locations] were not significantly different (nested ANOVA; $F=0.0002, d f=4$ and $114, p=1.000)$ suggesting that the reproducibility of the method was reliable. The $S_{Y \cdot X}$ values ranged from 0.025 to 0.162 (overall mean $=0.094 \pm 0.038$ ) in the thalli from Tarifa, and from 0.037 to 0.153 (overall mean $=0.090 \pm 0.025$ ) in the algae collected at Punta Calaburras, being significantly higher, at an $\alpha$ level of 0.05 , at Tarifa than at Punta Calaburras (nested ANOVA; $F=$ $14.041, d f=1$ and $4, p=0.040)$.

In situ temperature, solar radiation and photosynthetic performance

At Tarifa, the temperature of the air on $16^{\text {th }}$ July 2011 increased from $18.2{ }^{\circ} \mathrm{C}$ in early morning to an overall mean of $27.4 \pm 0.3{ }^{\circ} \mathrm{C}$ between 12.30 and $14.30 \mathrm{UTC}$, and then declined throughout the afternoon. The temperature of the seawater did not change significantly throughout the day, with an overall mean value of $19.5 \pm 0.1^{\circ} \mathrm{C}$. The air temperature records at Punta Calaburras were $21.1^{\circ} \mathrm{C}$ in early morning and a maximum of $28.2^{\circ} \mathrm{C}$ at noon; the seawater temperature ranged from 19.1 to $19.8^{\circ} \mathrm{C}$. 
Solar radiation data recorded at Punta Calaburras the following day were similar (data not

347 shown), with doses differing $< \pm 3 \%$.

The $F_{\mathrm{v}} / F_{\mathrm{m}}$ figures ranged from $0.674 \pm 0.035$ to $0.732 \pm 0.034$ during the day in permanently submerged thalli (Fig. 5A). The $F_{\mathrm{v}} / F_{\mathrm{m}}$ values were similar at both locations but a highly significant effect of time of day was detected (Table 3). The interaction between sampling location and time of day was not significant (Table 3). Under simulated emerged conditions, the values of $F_{\mathrm{v}} / F_{\mathrm{m}}$ significantly decreased from 10:00 to 14:00 (Fig. 5A), with a greater decrease in thalli from Punta Calaburras than those from Tarifa (Table 3). A significant interaction between locations and time of day was also found (Table 3). sampling location and time of day was not significant (Table 3). Under simulated emerged conditions the values of $\Phi_{\text {PSII }}$ significantly decreased from 10:00 to 14:00 (Fig. 5B; Table 3), with a greater decrease in thalli from Calaburras than those from Tarifa (Fig. 5B; Table 3). A significant interaction between locations and time of day was also found (Table 3). permanently submerged thalli (Fig. 5C). The $E T R_{\text {rel }}$ values were similar at both locations (Table 
366 conditions the values of $E T R_{\text {rel }}$ significantly decreased from 10:00 to 14:00 (Fig. 5C), with a

367 greater decrease in thalli from Calaburras than those from Tarifa (Fig. 5C; Table 3). A significant

368 interaction between locations and time of day was also found (Table 3).

369 The water content in algal fronds decreased when they were exposed to air (Fig. 5D),

370 with a greater decrease in thalli from Calaburras than those from Tarifa (Fig. 5D; Table 3). A

371 significant interaction between location and time of day was also found (Table 3).

372 We found that the hydration level significantly correlated $(p<0.0001, n=15)$ both with

$373 F_{\mathrm{v}} / F_{\mathrm{m}}(r=0.9407)$ and $\Phi_{\mathrm{PSII}}(r=0.9039)$.

374

375

376

377

378

379

380

381

382

383

384

385

386

387

Populations of fucoids living at the edge of their respective geographical distribution are being studied because shifts have occurred in recent decades (Viejo et al., 2011; Lamela-Silvarrey et al., 2012; Fernández, 2016). A survey of several populations of $F$. guiryi inhabiting the southernmost area of its geographical distribution (from Portugal to Western Sahara) showed that the species is restricted to upwelling areas, which can function as climate change refugia (Lourenço et al., 2016). Moreover, these authors highlighted that the population inhabiting the Strait of Gibraltar revealed the greatest genetic differentiation in comparison to other populations. The isolated population of $F$. guiryi inhabiting Punta Calaburras (Alboran Sea, Western Mediterranean Sea) serves as a model to understand the role of oceanographic and atmospheric conditions on the annual occurrence of thalli in midsummer. Recruitment of fewcelled stages could occur from the rapid settlement of nearby parental thalli (Serrão et al., 1996) when thalli survive year-to-year. However, after the disappearance of thalli in midsummer of a 
390 given year, the re-appearance of $F$. guiryi at Punta Calaburras could be achieved by the presence

391 of cryptic, microscopic stages that survive unfavourable summer months before developing again

392 during cooler months, or after catastrophic events (Creed et al., 1996; Carney \& Edwards, 2006;

393 Schiel \& Foster, 2006). Thus, local microscopic stages (recruits and holdfast remnants) at Punta

394 Calaburras could function as a "seed bank." An alternative hypothesis postulates that the re-

395 appearance of thalli in winter could result from the recruitment and establishment of embryos

396 transported from neighbouring populations in the Strait of Gibraltar (Conde \& Seoane-Camba,

397 1982; Conde, 1989), around 80 km from Punta Calaburras (see Fig. 1A). However, Neiva et al.

398 (2012) showed that microscopic stages of Fucus ceranoides L. are poorly dispersed at scales of

399 kilometres, and this is also possibly true for F. guiryi. With our data, we cannot discern whether

400 the recurring re-appearance of thalli in winter is due to immigration or local recruitment, or both.

401 Moreover, we found no regularities nor tendencies in the occurrence along the time series but,

402 obviously, the "switch-on switch-off" pattern of the thalli of F. guiryi at Punta Calaburras must

403 be under environmental control. For this reason, we evaluated oceanographic and atmospheric

404 factors that could be involved in the persistence of macroscopic thalli during the summer.

405 The survival of the thalli of F. guiryi at Punta Calaburras in midsummer correlates with

406 the overall mean NAO value recorded from April to June, with presence clearly favoured under

407 positive NAO, whereas the alga did not survive or did not develop from microscopic stages

408 under negative overall mean NAO values from April to June. It must be taken into account that

409 NAO is an atmospheric "teleconnection" pattern affecting the climatic conditions in the North

410 Atlantic region, and the derived NAO index is a measure of the strength of the sea level air

411 pressure gradient between Iceland and the Azores, which integrates several climatic variables

412 (e.g., water temperature, prevailing wind direction and speed, and precipitation). In the Alboran 
413 Sea, a significant relationship has been found between the negative NAO phase and an increase

414 of SST, possibly through increase in run-off (Báez et al., 2013). Consequently, it is possible to

415 consider a direct effect of SST on $F$. guiryi by NAO. The sequence of events for the persistence

416 until midsummer of $F$. guiryi thalli at Punta Calaburras could be the growth from microscopic,

417 cryptic stages, as well as the arrival of few-celled embryos originating from the populations

418 located on the shores of the Strait of Gibraltar in winter-spring; then, there can be growth of

419 young thalli if the SST remains relatively low. However, it could be hypothesized that the

420 survival of the thalli is favoured directly both by NAO, and SST resulting from NAO. Thus,

421 positive phases of the NAO during April and June produce dry springs and clear skies. On the

422 other hand, the position of the AJ is variable (Vargas-Yáñez et al., 2002; Macías et al., 2016)

423 with a north-south migration pattern (Sarhan et al., 2000). The speed of the incoming AJ

424 increases at low pressure over the western Mediterranean (García-Lafuente et al., 2002), and

425 decreasing Mediterranean sea-level has been related to positive NAO index (Tsimplis \& Josey,

426 2001). Increasing velocity enhances the Coriolis force and separates the AJ from the Spanish

427 coast, facilitating the upwelling of cold Mediterranean water $\left(14^{\circ} \mathrm{C}\right.$ to $\left.17^{\circ} \mathrm{C}\right)$ at the Spanish

428 coast and consequently allowing the survival of $F$. guiryi thalli, as was suggested by Lourenço et

429 al. (2016) in other locations where the alga appears associated with an upwelling. In contrast,

430 under negative NAO index, the AJ velocity might decrease and the Western Alboran gyre (see

431 Fig. 1A), characterized by warmer water, migrates northward and may reach the coast at Punta

432 Calaburras. This increases the probability of short-term periods of very warm water (up to $22^{\circ} \mathrm{C}$ )

433 that hinder survival of $F$. guiryi thalli under negative NAO index. It is significant that other

434 organisms do not proliferate on the substrate occupied by F. guiryi at Punta Calaburras. 
436 (AMO) on the growth of seaweeds has been recently recognized (Halfar et al., 2011), but we

437 cannot correlate our data to this phenomenon because our time series for $F$. guiryi is relatively 438 short.

When the thalli of $F$. guiryi at Punta Calaburras proliferate until midsummer, they do not

440 show evidences of physiological stress under submerged conditions, when compared to the 441 population at Tarifa. However, the photosynthetic performance of thalli at Punta Calaburras is

442 clearly less efficient in air than the counterpart population at the Strait of Gibraltar. The 443 narrower, and overall lower tidal range at Punta Calaburras in comparison to Tarifa (see Fig. 2)

444 ensures that the thalli of the former population remain almost permanently hydrated, whereas the 445 Tarifa thalli experience true submersion-emersion cycles, and consequently are better acclimated 446 to air exposure. It should be noted that the substrate available for the alga at Punta Calaburras is 447 scant, as the rocks do not protrude from the mean sea level more than $30 \mathrm{~cm}$. In contrast, the 448 substrates at Tarifa emerge more than $3 \mathrm{~m}$ above mean sea level. Thus, we can hypothesize that 449 the thalli at Tarifa lose water in air more slowly than those at Punta Calaburras. However, the 450 difference in water economy and photosynthetic performance when the thalli are exposed to air 451 is not reflected in the same way in the development instability. The population from Tarifa 452 showed a significantly higher standard error of the estimate of the regression derived from the 453 box-counting method than the population from Punta Calaburras. This result suggests that the 454 former population integrates a higher stress during ontogeny than thalli developing at Punta 455 Calaburras. More studies are necessary to clarify the relationships between stress estimates based 456 on rapid physiological responses and integrative responses during ontogeny. 

exception of water and carbon economy.

\section{ACKNOWLEDGMENTS}

The suggestions and criticisms of two anonymous reviewers as well as Dra. Ester A. Serrão are

\section{REFERENCES}

Báez JC, Gimeno L, Gómez-Gesteira, M, Ferri-Yáñez F, Real R. 2013. Combined effects of the North Atlantic Oscillation and the Arctic Oscillation on sea surface temperature in the Alborán Sea. PLoS One 8: e62201 DOI 10.1371/journal.pone.0062201.

Báez JC, Real R, López-Rodas V, Costas E, Salvo AE, García-Soto C, Flores-Moya A. 2014. The North Atlantic Oscillation and the Arctic Oscillation favor harmful algal blooms in SW Europe. Harmful Algae 39: 121-126 DOI 10.1016/j.hal.2014.07.008. 
481

482

483

484

485

486

487

488

489

490

491

492

493

494

495

496

497

498

499

500

501

502

503

504

505

506

507

Baker NR, Oxborough K. 2004. Chlorophyll fluorescence as a probe of photosynthetic productivity. In: Papageorgiou GC, ed. Chlorophyll a Fluorescence. A Signature of Photosynthesis. Netherlands: Springer, $65-82$.

Bellón L. 1953. Atlantic seaweeds of the Malagan coast (Western Mediterranean). Abstract Proceeding International Seaweed Symposium 1: 5.

Bermejo R, Ramírez-Romero E, Vergara JJ, Hernández I. 2015. Spatial patterns of macrophyte composition and landscape along the rocky shores of the Mediterranean-Atlantic transition region (northern Alboran Sea). Estuarine, Coastal and Shelf Science 155: 17-28. DOI 10.1016/j.ecss.2015.01.009Carney LT, Edwards MS. 2006. Cryptic processes in the sea: a review of delayed development in the microscopic life stages of marine macroalgae. Algae 21: 161-168. DOI 10.4490/ALGAE.2006.21.2.161.

Channell R, Lomolino MV. 2000. Dynamic biogeography and conservation of endangered species. Nature 403: 84-86 DOI 10.1038/47487.

Clarke GM, McKenzie JA. 1987. Developmental stability of insecticide resistant phenotypes in blowfly; a result of canalizing natural selection. Nature 325: 345-346 DOI 10.1038/325345a0.

Clarke GM. 1995. Relationships between developmental stability and fitness: Application for conservation biology. Conservation Biology 9: 18-24 DOI 10.1046/j.1523-1739.1995.09010018.x.

Conde F. 1989. Catálogo de las algas macrobentónicas marinas de Málaga. Acta Botanica Malacitana 9: 47-78.

Conde F, Seoane-Camba, JA. 1982. Corología de las especies de algas en relación a ciertos factores ecológicos en el litoral malagueño. Collectanea Botanica 13: 783-802.

Corbit JD, Garbary DJ. 1995. Fractal dimension as a quantitative measure of complexity in plant development. Proceedings: Biological Sciences 262: 1-6. DOI 10.1098/rspb.1995.0168.

Cox DR, Lewis PAW. 1978. The Statistical Analysis of Series of Events. London: Chapman and Hall.

Creed JC, Norton TA, Harding SP. 1996. The development of size structure in a young Fucus serratus population, European Journal of Phycology 31: 203-209. DOI: 10.1080/09670269600651391.

Eckert CG, Samis KE, Lougheed C. 2008. Genetic variation across species' geographical ranges: the centralmarginal hypothesis and beyond. Molecular Ecology 17: 1170-1188 DOI 10.1111/j.1365294X.2007.03659.x. 
508

509

510

511

512

513

514

515

516

517

518

519

520

521

522

523

524

525

526

527

528

529

530

531

532

533

Emlen JM, Freeman DC, Graham JH. 1993. Nonlinear growth dynamics and the origin of fluctuating asymmetry. Genetica 89: 77-96 DOI 10.1007/BF02424507.

Helmuth B, Mieszkowska N, Moore P, Hawkin S. 2006. Living on the edge of two changing worlds. Forecasting the responses of rocky intertidal ecosystems to climate change. Annual Review of Ecology, Evolution, and Systematics 37: 373-404 DOI 10.1146/annurev.ecolsys.37.091305.110149.

Fernández C. 2016. Current status and multidecadal biogeographical changes in rocky intertidal algal assemblages: The northern Spanish coast. Estuarine, Coastal and Shelf Science 171: 35-40. DOI 10.1016/j.ecss.2016.01.026.

Ferreira JG, Arenas F, Martínez B, Hawkins SJ, Jenkins SR. 2014. Physiological response of fucoid algae to environmental stress: comparing range centre and southern populations. New Phytologist 202: 1157-1172 DOI 10.1111/nph.12749.

Folland CK, Knight J, Linderholm HW, Fereday D, Ineson S, Hurrell JW. 2009. The summer North Atlantic Oscillation: past, present, and future. Journal of Climate 22: 1082-1103 DOI 10.1175/2008JCLI2459.1.

Gamboa G, Halfar J, Hetzinger S, Adey W, Zack T, Kunz B, Jacob DE. 2010. Mg/Ca ratios in coralline algae record northwest Atlantic temperature variations and North Atlantic Oscillation relationships. Journal of Geophysical Research 115: C12044 DI 10.1029/2010JC006262.

García-Lafuente J, Álvarez Fanjul E, Vargas JM, Ratsimandresy AW. 2002. Subinertial variability in the flow through the Strait of Gibraltar. Journal of Geophysical Research 107(C10), 3168 DOI 10.1029/2001JC001104.

Graham JH, Freeman DC, Emlen JM. 1993. Developmental stability: a sensitive indicator of populations under stress. ASTM Special Technical Publication 1179: 136-136 DOI 10.1520/STP19239S.

Halfar J, Hetzinger S, Adey W, Zack T, Gamboa G, Kunz B, Williams B, Jacob DE. 2011. Coralline algal growth-increment widths archive North Atlantic climate variability. Palaeogeography, Palaeoclimatology, Palaeoecology 302: 71-80 DOI 10.1016/j.palaeo.2010.04.009.

Hammer Ø, Harper DAT, Ryan PD. 2001. PAST: Paleontological statistics software package for education and data analysis. Palaeontologia Electronica 4:1-9. http://palaeo-electronica.org/2001_1/past/issue1_01.htm 
534 Helmuth B, Mieszkowska N, Moore P, Hawkins SJ. 2006. Living on the edge of two changing worlds:

535

536

537

538

539

540

541

542

543

544

545

546

547

548

549

550

551

552

553

554

555

556

557

558

559

forecasting the responses of rocky intertidal ecosystems to climate change. Annual Review of Ecology, Evolution, and Systematics 37: 373-404 DOI 10.1146/annurev.ecolsys.37.091305.110149.

Hosmer DW, Lemeshow S. 1980. A goodness of fit test for the multiple logistic regression model. Communications in Statistics-Theory and Methods 9: 1043-1069 DOI 10.1080/03610928008827941

Hurrell JW. 1995. Decadal trends in the North Atlantic Oscillation: Regional temperatures and precipitation. Science 269: 676-679 DOI 10.1126/science.269.5224.676.

Hurrell JW, Kushnir Y, Ottersen G, Visbeck M. 2003. An Overview of the North Atlantic Oscillation. In: Hurrell JW, Kushnir Y, Ottersen G, Visbeck Mm, eds. The North Atlantic Oscillation Climatic Significance and Environmental Impact. Washington DC: Geophysical Monograph, 134: 1-35.

Iannaccone PM, Khokha M. 1996. Fractal Geometry in Biological Systems: An Analytical Approach. Boca Raton: CRC Press.

Lamela-Silvarrey C, Fernández C, Anadón, Arrontes J. 2012. Fucoid assemblages on the north coast of Spain: past and present (1977 - 2007). Botanica Marina 55: 199-207. DOI 10.1515/bot-2011-0081.

Lobo JM, Jiménez-Valverde A, Real R. 2008. AUC: a misleading measure of the performance of predictive distribution models. Global Ecology and Biogeography 17: 145-151 DOI 10.1111/j.14668238.2007.00358.x.

Lourenço CR, Zardi GI, McQuaid CD, Serrão EA, Pearson GA, Jacinto R, Nicastro KR. 2016. Upwelling areas as climate change refugia for the distribution and genetic diversity of a marine macroalga. Journal of Biogeography 43: 1595-1607 DOI 10.1111/jbi.12744.

Macías D, García-Gorriz E, Stips A. 2016. The seasonal cycle of the Atlantic Jet dynamics in the Alboran Sea: direct atmospheric forcing versus Mediterranean thermohaline circulation. Ocean Dynamics 66: 137-151 DOI 10.1007/s10236-015-0914-y.

Mandelbrot B. 1983. The Fractal Geometry of Nature. New York: WH Freaman and Company.

McKenzie JA, Clarke GM. 1988. Diazinon resistance, fluctuating asymmetry and fitness in the Australian sheep blowfly, Lucilia cuprina. Genetics 1: 213-220 DOI 10/1988; 120(1):213-20. 
560

561

562

563

564

565

566

567

568

569

570

571

572

573

574

575

576

577

578

579

580

581

582

583

584

585

586

Moore SK, Trainer VL, Mantua NJ, Parker MS, Laws EA, Backer LC, Fleming LE. 2008. Impacts of climate variability and future climate change on harmful algal blooms and human health. Environmental Health 12: 1-12 DOI10.1186/1476-069X-7-S2-S4.

Muñoz M, Reul A, Plaza F, Gómez-Moreno M-L, Vargas-Yáñez M, Rodríguez V, Rodríguez J. 2015. Implication of regionalization and connectivity analysis for marine spatial planning and coastal management in the Gulf of Cadiz and Alboran Sea. Ocean and Coastal Management 118: 60-74 DOI 10.1016/j.ocecoaman.2015.04.011.

Nagelkerke NJD. 1991. A note on a general definition of the coefficient of determination. Biometrika 78: 691-692 DOI 10.1093/biomet/78.3.691

Palmer AR. 1994. Fluctuating asymmetry analyses: a primer. In: Markow TA, ed. Developmental Instability: its Origins and Evolutionary Implications. Netherlands: Kluwer Academic Publishers, 335-364.

Parrilla G, Kinder TH. 1987. Oceanografía física del Mar de Alborán. Boletín del Instituto Español de Oceanografia 4: 133-165.

Peterman WE, Feist SM, Semlitsch RD, Eggert LS. 2013. Conservation and management of peripheral populations: Spatial and temporal influences on the genetic structure of wood frog (Rana sylvatica) populations. Biological Conservation 158: 351-358 DOI 10.1016/j.biocon.2012.07.028.

Prahl J. 1999. A fast unbinned test on event clustering in Poisson processes. arXiv preprint astro-ph/9909399.

R Core Team (2013). R: A language and environment for statistical computing. R Foundation for Statistical Computing, Vienna, Austria. URL http://www.R-project.org/.

Renault L, Oguz T, Pascual L, Visozo G, Tintoré J. 2012. Surface circulation in the Alborán Sea (western Mediterranean) inferred from remotely sensed data. Journal of Geophysical Research 117: C08009 DOI 10.1029/2011JC007659.

Reul A, Rodríguez V, Jiménez-Gómez F, Blanco, JM, Bautista B, Sarhan T, Guerrero F, Ruíz J, GarcíaLafuente J. 2005. Variability in the spatio-temporal distribution and size-structure of phytoplankton across an upwelling area in the NW-Alboran Sea (W-Mediterranean). Continental Shelf Research 25: 589-608 DOI 10.1016/j.csr.2004.09.016.

Rodríguez J. 1982. Oceanografia del mar Mediterráneo. Madrid: Pirámide SA. 
587 Sancholle M. 1988. Présence de Fucus spiralis (Phaeophyceae) en Méditerranee occidentale. Cryptogamie,

588

589

590

591

592

593

594

595

596

597

598

599

600

601

602

603

604

605

606

607

608

609

610

611

612

613 Algologie 9: 157-161.

Sarhan T, García-Lafuente J, Vargas M, Vargas JM, Plaza F, 2000. Upwelling mechanisms in the Northwestern Alboran sea. Journal of Marine System 23, 317-331.

Schiel DR, Foster MS. 2006. The population biology of large brown seaweeds: ecological consequences of multiphase life histories in dynamic coastal environments. Annual Review of Ecology, Evolution, and Systematics 37: 343-372. DOI 10.1146/annurev.ecolsys.37.091305.110251.

Serrão EA, Pearson G, Kautsky L, Brawley SH. 1996. Successful external fertilization in turbulent environments. Proceedings of the National Academy of Sciences of the United States of America 93: 5286-5290.

Smale DA, Burrows MT, Moore P, O’Connor N, Hawkins SJ. 2013. Threats and knowledge gaps for ecosystem services provided by kelp forests: a northeast Atlantic perspective. Ecology and Evolution 3: 4016-4038 DOI 10.1002/ece3.774.

Schreiber U, Schliwa U, Bilger W. 1986. Continuous recording of photochemical and non-photochemical chlorophyll fluorescence quenching with a new type of modulation fluorometer. Photosynthesis research 10: 51-62 DOI 10.1007/BF00024185.

Schulze MM, Hutchings N, Simpson TL. 2008. The use of fractal analysis and photometry to estimate the accuracy of bulbar redness grading scales. Investigative Ophthalmology \& Visual Science 49: 1398-1406 DOI 10.1167/iovs.07-1306.

Shumaker KM, Babble GR. 1980. Patterns of allozymic similarity in ecologically central and marginal populations of Hordeum jubatum in Utah. Evolution 34: 110-116 DOI 10.2307/2408319.

Thompson DWJ, Wallace JW. 1998. The Arctic Oscillation signature in the wintertime geopotential height and temperature fields. Geophysical Research Letters 25: 1297-1300 DOI 10.1029/98g100950.

Timplis NM, Josey SA. 2001. Forcing of the Mediterranean Sea by atmospheric oscillations over the North Atlantic. Geophysical Research Letters 28: 803-806. DOI 10.1029/2000GL012098.

Vargas-Yáñes M, Plaza F, García-Lafuente J, Sarhan T, Vargas JM, Vélez-Belchí P. 2002. About the seasonal variability of the Alboran Sea circulation. Journal of Marine Systems 35: 229-248. DOI 10.1016/S09247963(02)00128-8. 
614 Viejo RM, Martínez B, Arrontes J, Astudillo C, Hernández L. 2011. Reproductive patterns in central and 615 marginal populations of a large brown seaweed: drastic changes at the southern range limit. Ecography 34: 616 75-84. DOI 10.1111/j.1600-0587.2010.06365.x.

617 Wald A. 1943. Test of statistical hypotheses concerning several parameters with applications to problems of 618 estimation. Transactions of the American Mathematical society 54: 426-482.

619 Walsh J, Watterson J. 1993. Fractal analysis of fracture pattern using the standard box-counting technique: valide and invalid methodologies. Journal of structural Geology 15: 1509-1521 DOI 10.1016/0191-8141(93)90010-

621 8.

Zakharov VM. 1992. Population phenogenetics: analysis of developmental stability in natural populations. Acta Zoologica Fennica 191: 7-30.

Zardi GI, Nicastro KR, Canovas F, Ferreira Costa J, Serrão EA, Pearson GA. 2011. Adaptive traits are maintained on steep selective gradients despite gene flow and hybridization in the intertidal zone. PLoS ONE 6(6): e19402 DOI 10.1371/journal.pone.0019402.

Zardi GI, Nicastro KR, Serrão EA, Jacinto R, Monteiro CA, Pearson GA. 2015. Closer to the rear edge: ecology and genetic diversity down the core-edge gradient of a marine macroalga. Ecosphere 6(2): 23 DOI 10.1890/ES14-00460.1.

Zuur A, Ieno EN, Smith GM. 2007. Analysing Ecological Data. New York: Springer Science and Business Media. 


\section{Table $\mathbf{1}$ (on next page)}

Time series (1990-2015) of presence (1)/ absence (0) of Fucus guiryi at Punta Calaburras.

Time series (1990-2015) of presence (1)/ absence (0) of Fucus guiryi at Punta Calaburras, and overall mean values of NAO and AO indexes (dimensionless), sea surface temperature (SST; units in ${ }^{\circ} \mathrm{C}$ ), air temperature (AT; units in ${ }^{\circ} \mathrm{C}$ ) and rainfall ( $\mathrm{R}$; units in $\mathrm{mm}$ ), for the previous month or the overall mean for the six previous months (suffixes 1-6). 
Table 1. Time series (1990-2015) of presence (1)/ absence (0) of Fucus guiryi at Punta de Calaburras , and overall mean values of NAO and AO indexes (dimensionless), sea surface temperature (SST; units in ${ }^{\circ} \mathrm{C}$ ), air temperature (AT; units in $\left.{ }^{\circ} \mathrm{C}\right)$ and rainfall $(\mathrm{R}$; units in $\mathrm{mm}$ ), for the previous month or the overall mean for the six previous months (suffixes 1-6).

Year Fucus $\mathrm{AO}_{1} \quad \mathrm{AO}_{2} \quad \mathrm{AO}_{3} \quad \mathrm{AO}_{4} \quad \mathrm{AO}_{5} \quad \mathrm{AO}_{6} \quad \mathrm{NAO}_{1} \mathrm{NAO}_{2} \mathrm{NAO}_{3} \mathrm{NAO}_{4} \mathrm{NAO}_{5} \mathrm{NAO}_{6} \mathrm{SST}_{1} \mathrm{SST}_{2} \mathrm{SST}_{3} \mathrm{SST}_{4} \mathrm{SST}_{5} \mathrm{SST}_{6} \mathrm{AT}_{1} \quad \mathrm{AT}_{2} \mathrm{AT}_{3} \mathrm{AT}_{4} \quad \mathrm{AT}_{5} \quad \mathrm{AT}_{6} \quad \mathrm{R}_{1} \quad \mathrm{R}_{2} \quad \mathrm{R}_{3} \quad \mathrm{R}_{4} \quad \mathrm{R}_{5}$ $\begin{array}{lllllllllllllllllllllllllllllllll}\mathrm{R}_{6} & 19.30 & 1 & 0.30 & 0.62 & 1.04 & 1.53 & 1.90 & 1.75 & -0.02 & -0.78 & 0.15 & 0.48 & 0.66 & 0.73 & 16.2 & 16.7 & 16.2 & 16.0 & 15.7 & 15.7 & 21.4 & 20.3 & 18.8 & 17.9 & 17.3 & 16.6 & 25 & 153 & 118 & 324\end{array}$ $346 \quad 469$

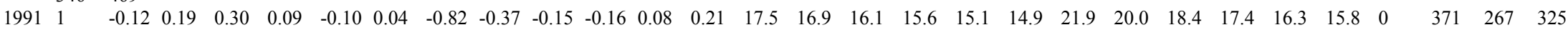
$307 \quad 377$

$\begin{array}{lllllllllllllllllllllllllllllll}1992 & 1 & -0.30 & 0.52 & 0.17 & 0.38 & 0.52 & 0.53 & 0.20 & 1.42 & 1.56 & 1.39 & 1.33 & 1.08 & 14.4 & 15.8 & 15.3 & 15.2 & 14.9 & 14.7 & 18.8 & 19.0 & 18.2 & 17.3 & 16.4 & 15.7 & 270 & 140 & 493 & 472\end{array}$ $497 \quad 450$

$\begin{array}{lllllllllllllllllllllllllllllll}1993 & 1 & -0.52 & -1.06 & -0.85 & -0.45 & -0.32 & 0.31 & -0.59 & -0.69 & -0.13 & 0.07 & 0.15 & 0.40 & 16.2 & 15.6 & 15.2 & 15.0 & 14.9 & 14.7 & 20.7 & 19.2 & 17.9 & 16.8 & 16.0 & 15.4 & 0 & 103 & 209 & 323\end{array}$ $384 \quad 400$

$\begin{array}{lllllllllllllllllllllllllllllll}1994 & 1 & 1.61 & 0.75 & 0.57 & 0.90 & 0.55 & 0.41 & 1.52 & 0.48 & 0.70 & 0.84 & 0.76 & 0.81 & 17.6 & 16.2 & 15.6 & 15.4 & 15.0 & 14.8 & 20.8 & 19.4 & 18.2 & 17.5 & 16.6 & 16.0 & 25 & 208 & 397 & 482\end{array}$ $599 \quad 579$

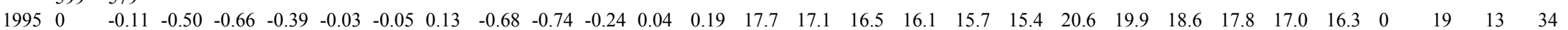
$\begin{array}{lllllllllllllllllllllllllllllllllllllll}1996 & 143 & 368 & 0.50 & 0.14 & -0.42 & -0.68 & -0.51 & -0.63 & 0.56 & -0.25 & -0.22 & -0.23 & -0.20 & -0.18 & 19.0 & 17.3 & 16.8 & 16.3 & 15.9 & 15.7 & 21.6 & 19.7 & 18.7 & 17.7 & 16.7 & 16.4 & 65 & 194 & 287 & 284\end{array}$

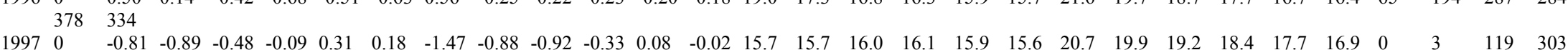
$502 \quad 797$

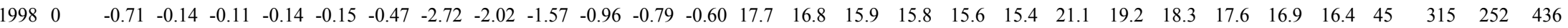
$531 \quad 550$

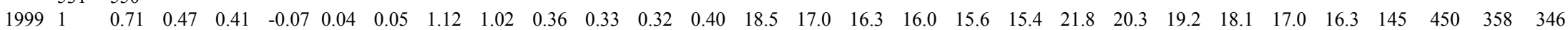
$\begin{array}{llllllllllllllllllllllllllllllllllll} & 277 & 234 & 1 & 0.59 & 0.78 & 0.43 & 0.21 & 0.38 & 0.53 & -0.03 & 0.78 & 0.51 & 0.57 & 0.80 & 0.77 & 20.4 & 18.5 & 16.9 & 16.6 & 16.3 & 15.9 & 22.6 & 20.7 & 19.0 & 18.1 & 17.4 & 16.5 & 147 & 472 & 522 & 472\end{array}$ $729 \quad 766$

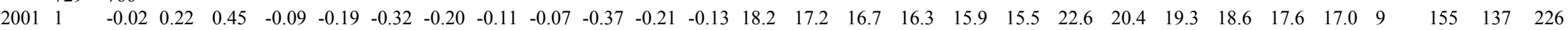
$181 \quad 175$

$\begin{array}{llllllllllllllllllllllllllllll}2002 & 1 & 0.57 & 0.49 & 0.57 & 0.66 & 0.79 & 0.88 & 0.38 & 0.08 & 0.45 & 0.51 & 0.63 & 0.60 & 16.6 & 16.3 & 16.1 & 15.8 & 15.7 & 15.5 & 21.3 & 20.1 & 18.7 & 17.8 & 17.1 & 16.5 & 916 & 600 & 909 & 980\end{array}$ 785773

$\begin{array}{lllllllllllllllllllllllllllllllll}2003 & 1 & -0.10 & 0.46 & 0.25 & 0.42 & 0.36 & 0.22 & -0.07 & -0.03 & -0.08 & 0.02 & 0.14 & 0.14 & 19.0 & 18.4 & 17.5 & 17.0 & 16.5 & 16.1 & 22.9 & 21.5 & 19.8 & 18.6 & 17.5 & 16.7 & 147 & 366 & 253 & 498\end{array}$ 725651

$\begin{array}{lllllllllllllllllllllllllllllll}2004 & 1 & -0.24 & -0.17 & -0.25 & -0.11 & -0.39 & -0.61 & -0.89 & -0.35 & 0.15 & 0.37 & 0.27 & 0.17 & 19.1 & 17.5 & 16.8 & 16.4 & 16.0 & 15.8 & 22.5 & 19.9 & 18.6 & 17.6 & 16.7 & 16.3 & 3 & 246 & 386 & 488\end{array}$ $430 \quad 462$

$\begin{array}{llllllllllllllllllllllllllllll}2005 & 0 & -0.38 & -0.57 & -0.40 & -0.64 & -0.76 & -0.58 & -0.05 & -0.65 & -0.53 & -0.86 & -0.70 & -0.33 & 18.3 & 17.5 & 16.7 & 16.1 & 15.6 & 15.4 & 22.2 & 20.9 & 19.6 & 18.2 & 16.9 & 16.0 & 0 & 56 & 46 & 229\end{array}$ $560 \quad 487$

$\begin{array}{lllllllllllllllllllllllllllllllll}2006 & 1 & 1.07 & 0.61 & 0.45 & -0.06 & -0.08 & -0.09 & 0.84 & -0.15 & 0.31 & -0.09 & -0.17 & 0.07 & 18.7 & 18.3 & 17.3 & 16.4 & 15.9 & 15.7 & 21.6 & 20.8 & 19.6 & 18.6 & 17.7 & 17.3 & 103 & 233 & 450 & 736\end{array}$ 791816

$\begin{array}{llllllllllllllllllllllllllllll}620070 & -0.55 & 0.17 & 0.29 & 0.52 & 0.15 & 0.47 & -1.31 & -0.32 & -0.16 & 0.24 & 0.10 & 0.12 & 16.0 & 15.7 & 15.3 & 15.0 & 15.0 & 15.1 & 20.6 & 19.8 & 18.5 & 17.6 & 17.0 & 16.3 & 1283 & 1640 & 1110 & 1365\end{array}$ 12931219

$\begin{array}{llllllllllllllllllllllllllllllll}2008 & 0 & -0.09 & -0.65 & -0.58 & -0.29 & -0.05 & 0.10 & -1.39 & -1.56 & -1.39 & -1.03 & -0.67 & -0.41 & 18.4 & 17.2 & 16.7 & 16.5 & 16.2 & 16.1 & 21.7 & 20.0 & 19.0 & 18.2 & 17.5 & 17.0 & 673 & 2209 & 3031 & 2482\end{array}$ 21321777

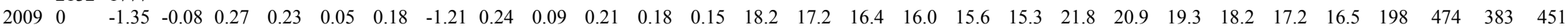
$373 \quad 311$

$\begin{array}{lllllllllllllllllllllllllllllllll}2010 & 0 & -0.01 & -0.47 & -0.40 & -0.41 & -1.18 & -1.42 & -0.82 & -1.15 & -1.01 & -0.98 & -1.18 & -1.17 & 17.9 & 17.2 & 17.0 & 16.4 & 16.0 & 15.7 & 20.6 & 19.4 & 18.5 & 17.5 & 16.9 & 16.3 & 246 & 466 & 370 & 602\end{array}$ $547 \quad 456$ 
$\begin{array}{lllllllllllllllllllllllllllllll}50 & 2011 & 1 & -0.86 & -0.45 & 0.46 & 0.70 & 0.88 & 0.45 & -1.28 & -0.67 & 0.38 & 0.44 & 0.49 & 0.26 & 19.2 & 18.6 & 17.8 & 17.2 & 16.9 & 16.7 & 21.5 & 20.6 & 19.5 & 18.4 & 17.5 & 16.8 & 588 & 761 & 560 & 809\end{array}$ $\begin{array}{rrrr}51 & 700 & 583\end{array}$

$\begin{array}{llllllllllllllllllllllllllllllllllll}52 & 2012 & 0 & -0.67 & -0.25 & -0.18 & 0.12 & 0.09 & 0.04 & -2.53 & -1.72 & -0.99 & -0.43 & -0.26 & -0.02 & 18.4 & 17.3 & 16.3 & 15.8 & 15.6 & 15.5 & 22.1 & 20.5 & 19.1 & 17.9 & 16.6 & 16.0 & 32 & 899 & 1047 & 804\end{array}$ $53 \quad 643 \quad 536$

$\begin{array}{lllllllllllllllllllllllllllllllllllll}54 & 2013 & 0 & 0.55 & 0.52 & 0.45 & -0.46 & -0.57 & -0.57 & 0.52 & 0.54 & 0.59 & 0.04 & -0.06 & 0.01 & 17.1 & 16.3 & 15.9 & 15.4 & 15.0 & 14.9 & 20.3 & 19.1 & 18.0 & 17.2 & 16.4 & 16.0 & 8 & 294 & 361 & 271\end{array}$ $\begin{array}{llllllllllllllllllllllllllllllllllll}55 & 217 & 181 & 2014 & 0 & -0.51 & -0.02 & 0.31 & 0.53 & 0.44 & 0.20 & -0.97 & -0.95 & -0.53 & -0.20 & 0.11 & 0.14 & 18.1 & 18.1 & 17.7 & 17.0 & 16.4 & 16.1 & 21.3 & 20.1 & 19.2 & 18.1 & 17.3 & 16.8 & 691 & 346 & 235 & 177\end{array}$ $\begin{array}{lll}57 & 185 & 189\end{array}$

$\begin{array}{lllllllllllllllllllllllllllllll}58 & 2015 & 0 & 0.43 & 0.59 & 0.80 & 1.06 & 1.06 & 1.06 & -0.07 & 0.04 & 0.27 & 0.56 & 0.72 & 0.89 & 17.7 & 17.1 & 16.4 & 16.0 & 15.7 & 15.5 & 21.7 & 20.1 & 18.6 & 17.7 & 16.8 & 16.2 & 1175 & 1008 & 744 & 607\end{array}$ 


\section{Table 2 (on next page)}

Binary logistic regression between presence/absence of Fucus guiryi as a function of NAO and AO indexes, sea surface temperature (SST), air temperature (AT) and rainfall $(\mathrm{R})$.

Value of $\chi^{2}$-test ( $d f=1$ in all of the cases) and associated probability, and Akaike Information Criterion (AIC), in the first step of the binary logistic regression between presence/absence of Fucus guiryi as a function of NAO and AO indexes, sea surface temperature (SST), air temperature (AT) and rainfall (R), for the previous month or the overall mean for the six previous months (suffixes 1-6). The asterisk shows the independent variable selected for the analyses based on the higher explanatory power. 
1 Table 2. Value of $\chi^{2}$-test ( $d f=1$ in all of the cases) and associated probability, and Akaike

2 Information Criterion (AIC), in the first step of the binary logistic regression between

3 presence/absence of Fucus guiryi as a function of NAO and AO indexes, sea surface temperature 4 (SST), air temperature (AT) and rainfall (R), for the previous month or the overall mean for the 5 six previous months (suffixes 1-6). The asterisk shows the independent variable selected for the 6 analyses based on the higher explanatory power.

\begin{tabular}{|c|c|c|c|}
\hline Variables & $\chi^{2}$ & $p$ & AIC \\
\hline $\mathrm{AO}_{1}$ & 3.785 & 0.045 & 36.035 \\
\hline $\mathrm{AO}_{2}$ & 4.735 & 0.029 & 35.308 \\
\hline $\mathrm{AO}_{3}$ & 4.656 & 0.031 & 35.387 \\
\hline $\mathrm{AO}_{4}$ & 3.208 & 0.073 & 36.835 \\
\hline $\mathrm{AO}_{5}$ & 3.364 & 0.066 & 36.680 \\
\hline $\mathrm{AO}_{6}$ & 3.384 & 0.060 & 36.516 \\
\hline $\mathrm{NAO}_{1}$ & 5.532 & 0.018 & 34.511 \\
\hline $\mathrm{NAO}_{2}$ & 6.824 & 0.008 & 33.220 \\
\hline $\mathrm{NAO}_{3}{ }^{*}$ & 13.530 & 0.0002 & 26.513 \\
\hline $\mathrm{NAO}_{4}$ & 10.543 & 0.001 & 29.501 \\
\hline $\mathrm{NAO}_{5}$ & 9.910 & 0.001 & 30.133 \\
\hline $\mathrm{NAO}_{6}$ & 9.431 & 0.002 & 30.612 \\
\hline $\mathrm{SST}_{1}$ & 0.028 & 0.866 & 40.015 \\
\hline $\mathrm{SST}_{2}$ & 0.386 & 0.543 & 39.658 \\
\hline $\mathrm{SST}_{3}$ & 0.006 & 0.941 & 40.038 \\
\hline $\mathrm{SST}_{4}$ & 0.008 & 0.930 & 40.036 \\
\hline $\mathrm{SST}_{5}$ & 0.011 & 0.916 & 40.033 \\
\hline $\mathrm{SST}_{6}$ & 0.019 & 0.890 & 40.024 \\
\hline $\mathrm{AT}_{1}$ & 0.899 & 0.343 & 39.168 \\
\hline $\mathrm{AT}_{2}$ & 0.760 & 0.383 & 39.294 \\
\hline $\mathrm{AT}_{3}$ & 0.670 & 0.769 & 39.991 \\
\hline $\mathrm{AT}_{4}$ & 0.480 & 0.826 & 39.967 \\
\hline $\mathrm{AT}_{5}$ & 0.017 & 0.896 & 40.036 \\
\hline $\mathrm{AT}_{6}$ & 0.005 & 0.942 & 40.035 \\
\hline $\mathrm{R}_{1}$ & 1.184 & 0.277 & 38.860 \\
\hline $\mathrm{R}_{2}$ & 2.378 & 0.123 & 37.665 \\
\hline $\mathrm{R}_{3}$ & 1.110 & 0.292 & 38.933 \\
\hline $\mathrm{R}_{4}$ & 0.433 & 0.511 & 39.611 \\
\hline $\mathrm{R}_{5}$ & 0.386 & 0.534 & 39.658 \\
\hline $\mathrm{R}_{6}$ & 0.263 & 0.608 & 39.781 \\
\hline
\end{tabular}




\section{Table 3(on next page)}

Two-way anovas for the comparison of the $F_{\mathrm{v}} / F_{\mathrm{m}}, \Phi_{\mathrm{PS} \|}, E T R_{\text {rel }}$ and water tissue content of Fucus guiryi.

Two-way anovas for the comparison of the $F_{\mathrm{v}} / F_{\mathrm{m}}, \Phi_{\text {PSIII }}, E T R_{\text {rel }}$ and water tissue content of Fucus guiryi, and Student-Newman-Keuls (SNK) post-hoc test for significant (95\%) sources of variation. 
Table 3. Two-way ANOVAS for the comparison of the $F_{\mathrm{v}} / F_{\mathrm{m}}, \Phi_{\mathrm{PSII}}, E T R_{\mathrm{rel}}$ and water tissue content of Fucus guiryi, and Student2 Newman-Keuls (SNK) post-hoc test for significant (95\%) sources of variation.

\begin{tabular}{|c|c|c|c|c|c|c|c|}
\hline Variable & Source of variation & $d f$ & $\mathrm{SS}$ & MS & $F$ & $p$ & SNK \\
\hline \multirow{2}{*}{$\overline{F_{\mathrm{v}} / F_{\mathrm{m}} \text { in water }}$} & Locations & 1 & 0.0001 & 0.0001 & 2.679 & 0.107 & \\
\hline & Time of day & 6 & 0.0492 & 0.0082 & 296.800 & 0.000 & \\
\hline \multicolumn{8}{|c|}{$6: 00=8: 00>18: 00>10: 00=16: 00>14: 00>12: 00$} \\
\hline & Locations $\times$ Time of day & 6 & 0.0002 & 0.0000 & 1.304 & 0.270 & \\
\hline & Error & 56 & 0.0015 & 0.0000 & & & \\
\hline \multirow[t]{4}{*}{$F_{\mathrm{v}} / F_{\mathrm{m}}$ in air } & Locations & 1 & 0.0269 & 0.0269 & 17.960 & 0.000 & Tarifa $>$ Calaburras \\
\hline & Time of day & 2 & 0.3569 & 0.1785 & 119.000 & 0.000 & $10: 00>12: 00>14: 00$ \\
\hline & Locations $\times$ Time of day & 2 & 0.0172 & 0.0086 & 5.726 & 0.009 & \\
\hline & Error & 24 & 0.0360 & 0.0015 & & & \\
\hline \multirow[t]{2}{*}{$\Phi_{\text {PSII }}$ in water } & Locations & 1 & 0.0021 & 0.0021 & 3.209 & 0.078 & \\
\hline & Time of day & 6 & 1.5120 & 0.2520 & 384.000 & 0.000 & \\
\hline \multicolumn{8}{|c|}{$6: 00>8: 00>18: 00>16: 00>10: 00>14: 00=12: 00$} \\
\hline & Locations $\times$ Time of day & 6 & 0.0018 & 0.0003 & 0.455 & 0.838 & \\
\hline & Error & 56 & 0.0368 & 0.0007 & & & \\
\hline \multirow[t]{4}{*}{$\Phi_{\mathrm{PSII}}$ in air } & Locations & 1 & 0.0167 & 0.0167 & 32.480 & 0.000 & Tarifa $>$ Calaburras \\
\hline & Time of day & 2 & 0.2320 & 0.1160 & 225.500 & 0.000 & $10: 00>12: 00>14: 00$ \\
\hline & Locations $\times$ Time of day & 2 & 0.0061 & 0.0030 & 5.889 & 0.008 & \\
\hline & Error & 24 & 0.0124 & 0.0005 & & & \\
\hline \multirow[t]{2}{*}{$E T R_{\text {rel }}$ in water } & Locations & 1 & 3764 & 3764 & 3.296 & 0.075 & \\
\hline & Time of day & 6 & 2154000 & 358900 & 314.300 & 0.000 & \\
\hline \multicolumn{8}{|c|}{$8: 00=12: 00>10: 00>14: 00>16: 00>6: 00>18: 00$} \\
\hline & Locations $\times$ Time of day & 6 & 3617 & 603 & 0.528 & 0.785 & \\
\hline & Error & 56 & 63940 & 1142 & & & \\
\hline \multirow[t]{4}{*}{$E T R_{\text {rel }}$ in air } & Locations & 1 & 60450 & 60450 & 32.800 & 0.000 & Tarifa $>$ Calaburras \\
\hline & Time of day & 2 & 655700 & 327800 & 177.900 & 0.000 & $10: 00>12: 00>14: 00$ \\
\hline & Locations $\times$ Time of day & 2 & 26430 & 13210 & 7.169 & 0.004 & \\
\hline & Error & 24 & 44230 & 1843 & & & \\
\hline \multirow[t]{4}{*}{ Water of tissue in air } & Locations & 1 & 326.7 & 326.7 & 49.630 & 0.0003 & Tarifa $>$ Calaburras \\
\hline & Time of day & 2 & 3712.0 & 1856.0 & 281.900 & 0.0000 & $10: 00>12: 00>14: 00$ \\
\hline & Locations $\times$ Time of day & 2 & 175.4 & 87.7 & 13.320 & 0.0001 & \\
\hline & Error & 24 & 158.0 & 6583.0 & & & \\
\hline
\end{tabular}




\section{Figure 1}

Map of study sites, oceanographic conditions and herbarium sheets.

Map of the area near the Strait of Gibraltar (A) showing the two sampling points of Fucus guiryi on the SW Iberian Peninsula (Tarifa and Punta Calaburras). Mean Sea Surface Temperature (SST) of weekly SST images 1998-2014 (cold upwelled water in blue (17으) and warm water of the Western Alboran Anticyclon in red $\left(20^{\circ} \mathrm{C}\right)$ as well as a schematic circulation pattern. Herbarium sheets of F. guiryi collected at Punta Calaburras (B) and Tarifa (C). It must be noted that the samples are identified according to the synonim Fucus spiralis. 


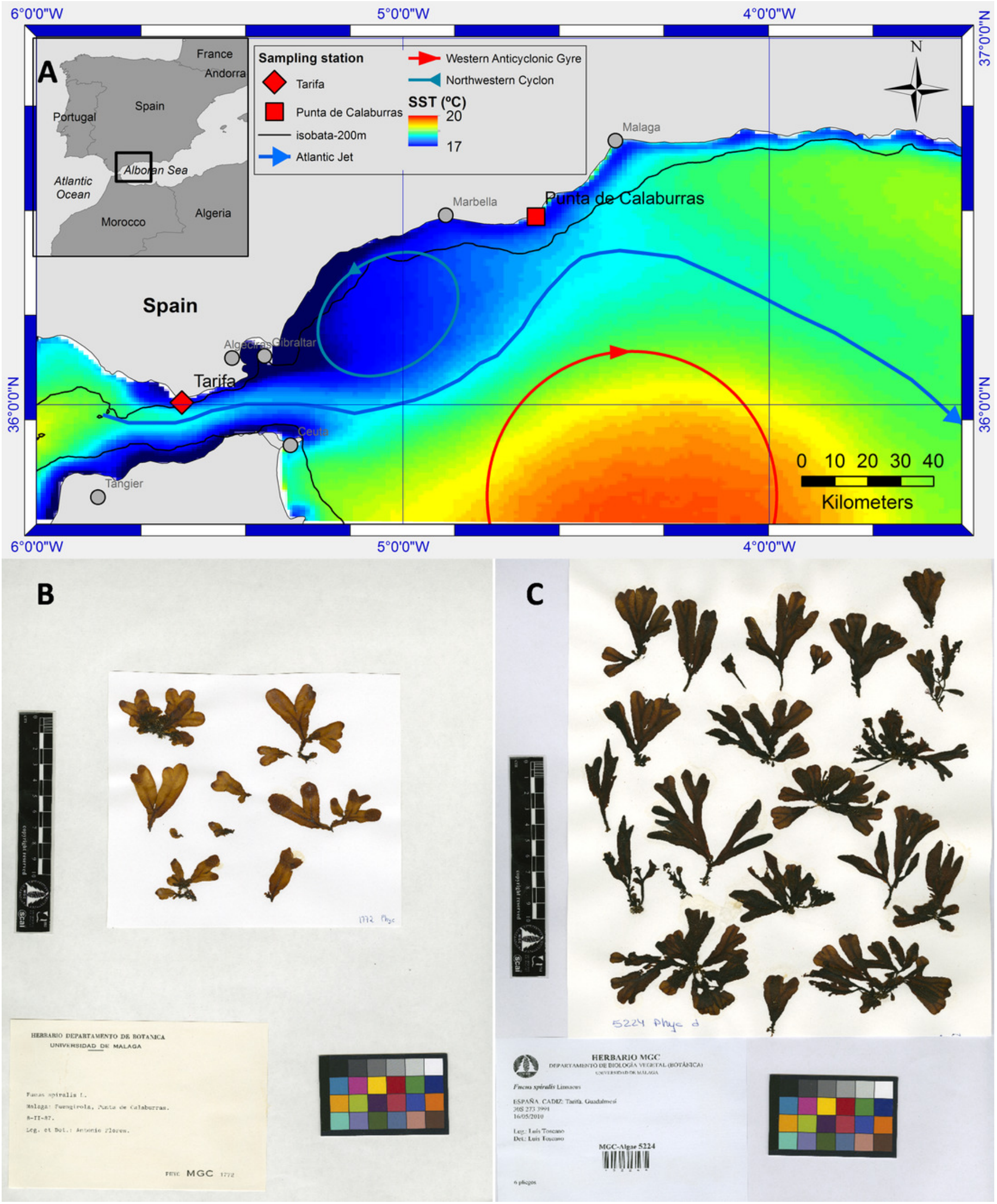


Figure 2 (on next page)

Tidal range and vertical ranges of Fucus guiryi at Tarifa and at Punta Calaburras

Daily (hours:minutes, Coordinated Universal Time) tidal height at Tarifa and maximum tidal range at Punta Calaburras on $16^{\text {th }}$ July 2011, and vertical ranges of Fucus guiryi at Tarifa and Punta Calaburras. Daily tidal regime at Punta Calaburras has not been included because no data are available. 


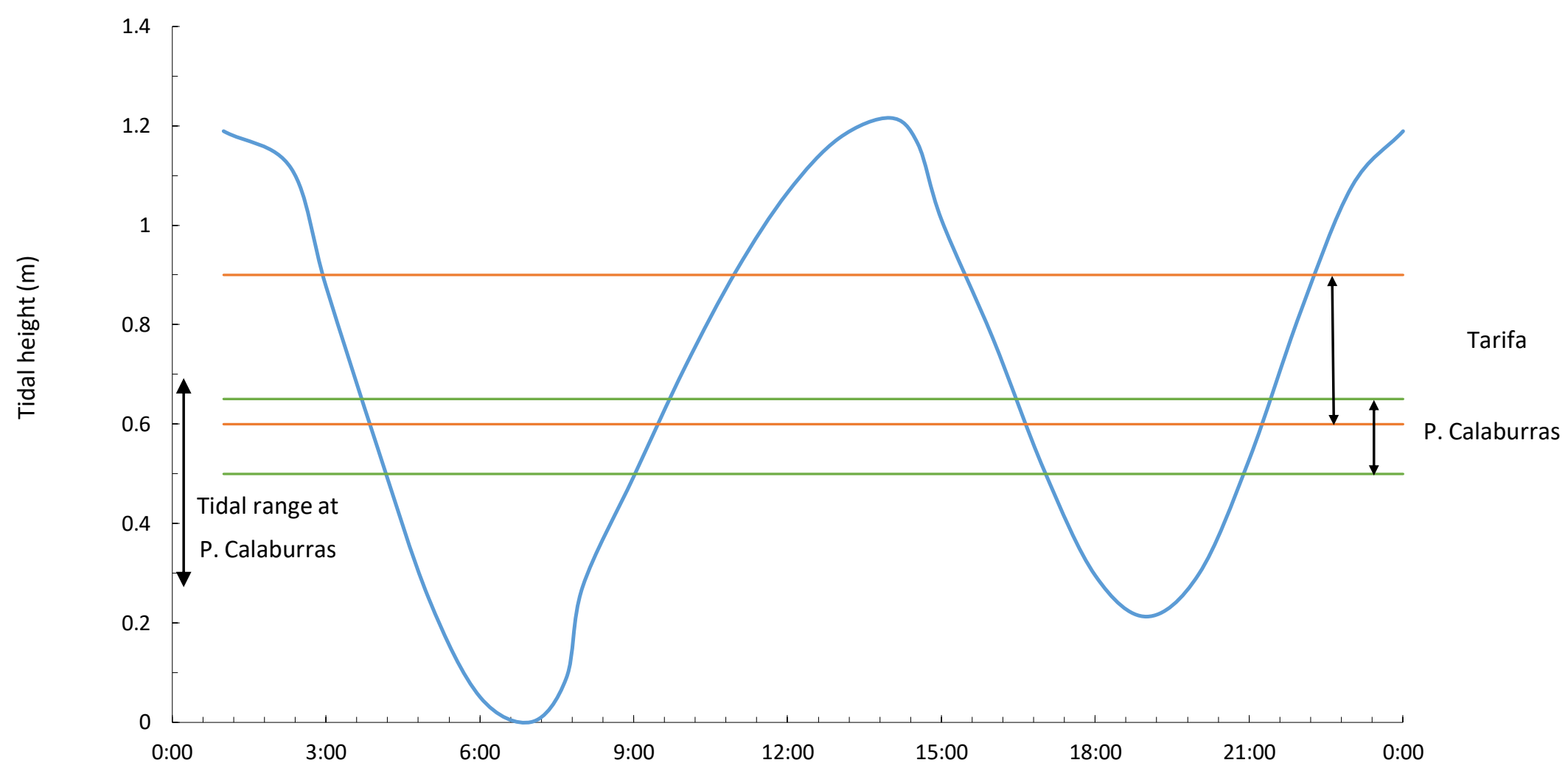




\section{Figure 3 (on next page)}

Binary logistic regression of occurence of Fucus guiryi as a function of $\mathrm{NAO}_{3}$

Probability (white circles) and presence (1)/absence (0) (black circles) of Fucus guiryi at Punta de Calaburras from 1990 to 2015, as a function of the North Atlantic Oscillation averaged for the months between April and June $\left(\mathrm{NAO}_{3}\right)$, as explanatory independent, environmental variable. 


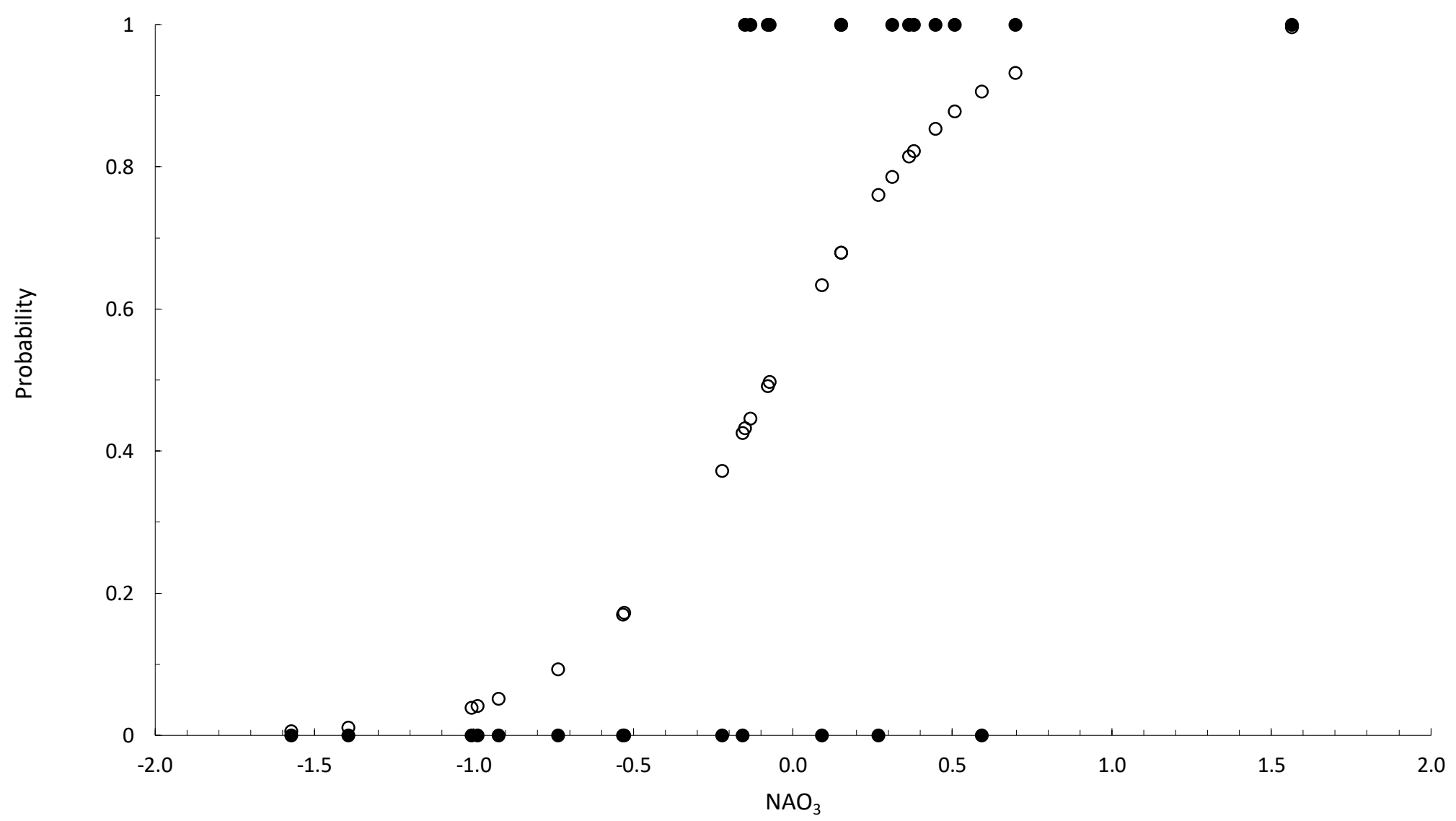


Figure 4 (on next page)

Daily course of PAR, UV-A and UV-B solar radiation

Daily course of PAR (black circles, continuous line), and UV-A (white circles, dotted line) and UV-B (black squares, dotted line) radiation at Tarifa, on 16 $6^{\text {th }}$ July 2011. 


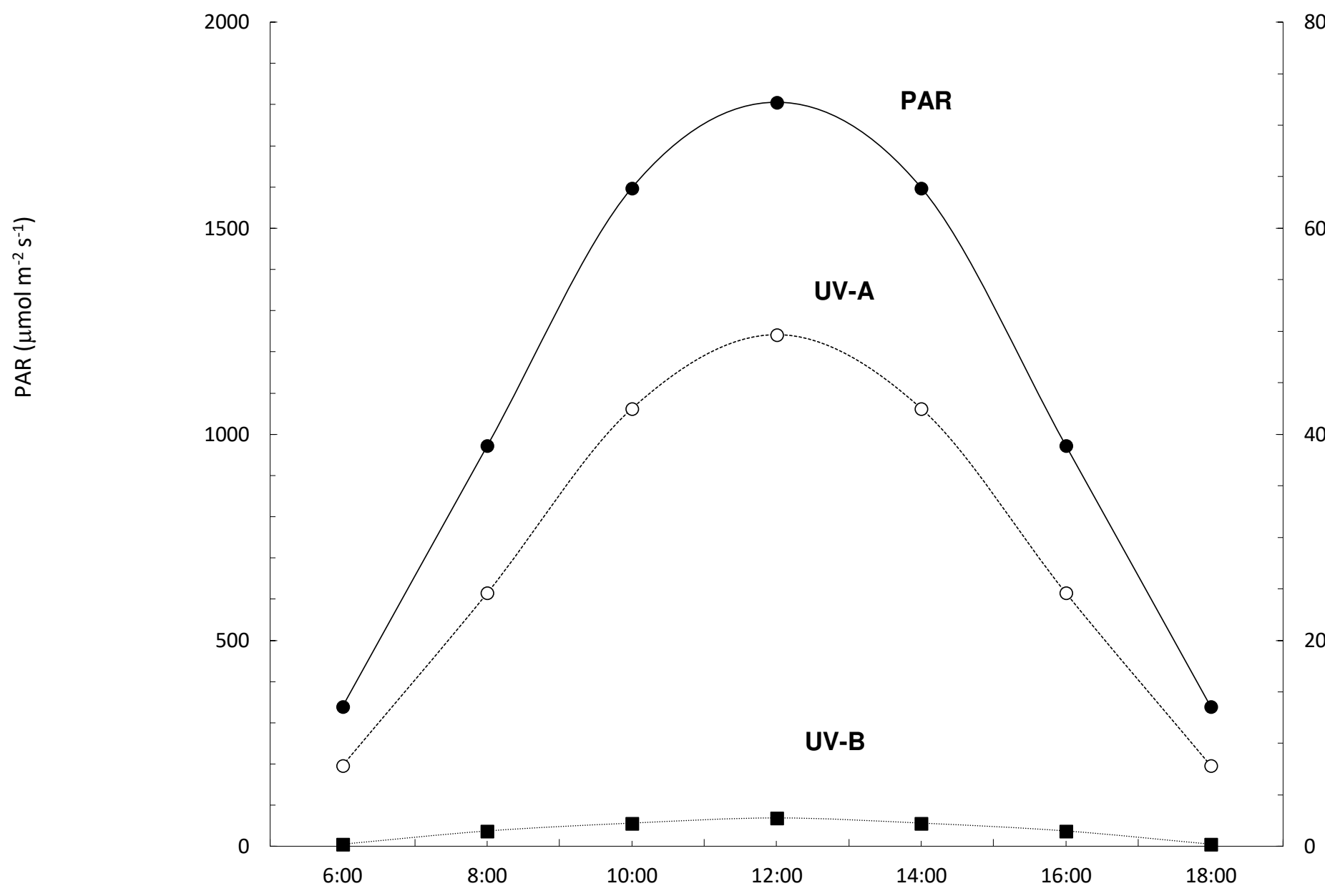


Figure $\mathbf{5}$ (on next page)

Daily course (hours:minutes, Coordinated Universal Time) of the $F_{\mathrm{v}} / F_{\mathrm{m}}(\mathrm{A}), \Phi_{\text {PSII }}(\mathrm{B}), E T R_{\text {rel }}$ (C) and water tissue content (D) of Fucus guiryi

Daily course (hours:minutes, Coordinated Universal Time) of the $F_{\mathrm{v}} / F_{\mathrm{m}}(\mathrm{A}), \Phi_{\mathrm{PSII}}(\mathrm{B}), E T R_{\text {rel }}(\mathrm{C})$ and water tissue content (D) of Fucus guiryi from Tarifa (black symbols, continuous lines) and from Punta de Calaburras (white symbols, dotted lines) in air (squares) and water (circles). The measurements were carried out on $16^{\text {th }}$ July 2011 in Tarifa, and the next day in Punta de Calaburras. 

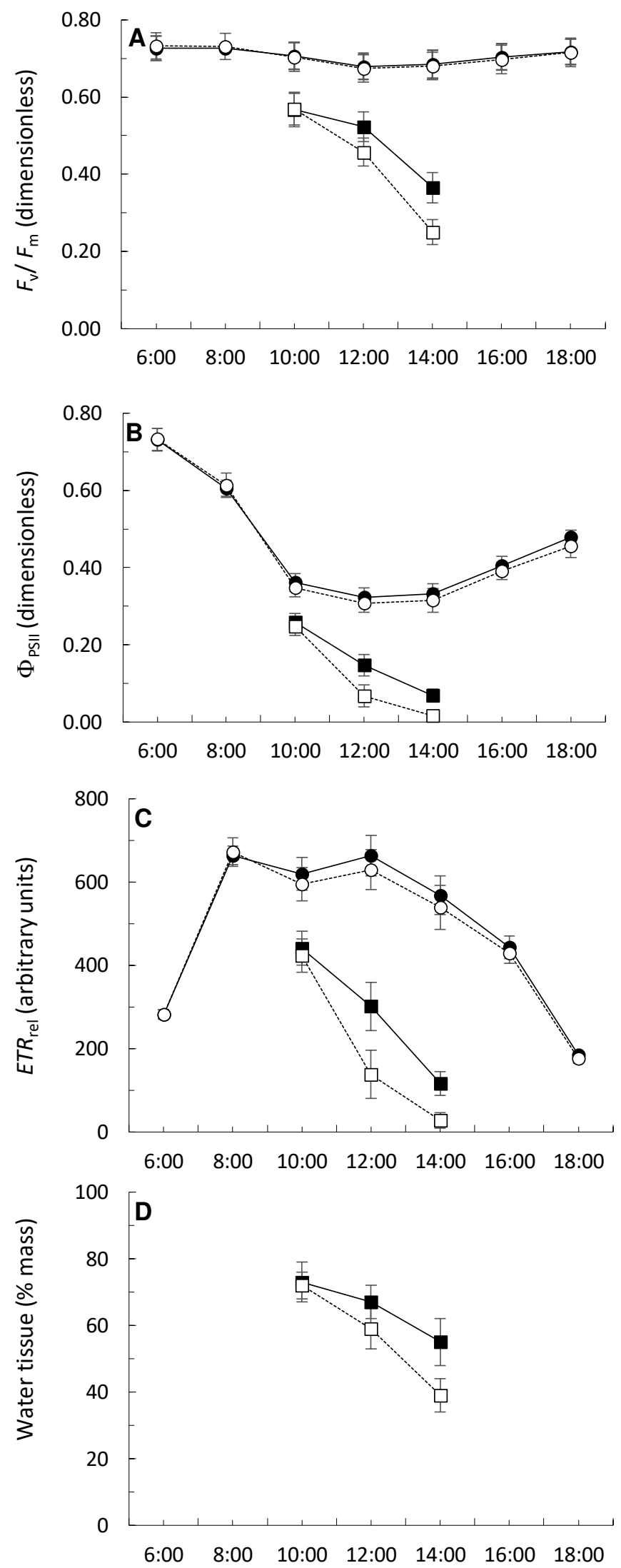